Poznańskie Studia Teologiczne 27(2013), s. 167-191.

Antoni Swoboda

Uniwersytet im. Adama Mickiewicza w Poznaniu

Wydział Teologiczny

\title{
Kształtowanie samoświadomości moralnej małżonka w nauczaniu św. Augustyna z Hippony
}

W obecnych czasach wiele osób stawia sobie pytanie, jaki winien być mężczyzna i małżonek w życiu osobistym, rodzinnym i społecznym, czy wystarczy, by był zdrowy, silny i bogaty. Odpowiedzi na tego typu pytania szukano także w starożytności, tej przed chrześcijaństwem, jak i w chrześcijaństwie pierwszych wieków. W literaturze starożytności niechrześcijańskiej znajduje się wiele świadectw zainteresowania tymi zagadnieniami. Można tu wymienić choćby pisma autorów tej miary, co Platon ${ }^{1}$ czy Arystoteles ${ }^{2}$. Trudno w tym miejscu nie wspomnieć żyjącego już na przełomie I i II wieku pisarza starożytnej Grecji, Plutarcha z Cheronei ${ }^{3}$ autora wielu prac, wśród których na uwagę zasługują Coniugalia praecepta i Vitae parallelae. Znajdujemy w nich nie tylko pogłębione refleksje na temat małżeństwa, ale także możemy zapoznać się ze wskazaniami odnoszącymi się do małżonków.

Ta tematyka podejmowana była także w środowisku łacińskim, czego przykładem może być twórczość mówcy, stylisty i filozofa Cycerona ${ }^{4}$, autora pracy De officiis adresowanej do syna Marka, czy filozofa Seneki ${ }^{5}$, który w swych Epistulae Morales ad Lucilium dotyka tematu formacji moralnej mężczyzny.

Również w literaturze okresu wczesnego chrześcijaństwa nie brak wypowiedzi na temat rodziny, żony, męża, ojca czy matki. Pierwsze wzmianki dotyczące tych zagadnień spotykamy już na przykład u należącego do ojców apostolskich Klemensa Rzymskiego ${ }^{6}$. Trudno też nie wspomnieć o Klemensie Aleksandryjskim ${ }^{7}$ i jego Stromatach, a zwłaszcza o biskupie Mediolanu, Ambrożym ${ }^{8}$ autorze De of-

\footnotetext{
${ }^{1}$ Platon (427-347 przed Chr.).

${ }^{2}$ Arystoteles (384-322 przed Chr.).

${ }^{3}$ Plutarch z Cheronei (ok. 50-ok. 120).

${ }^{4}$ Marcus Tullius Cicero (106-43 przed Chr.).

${ }^{5}$ Lucius Annaeus Seneca (ok. 60 przed Chr.-40 po Chr.).

${ }^{6}$ Klemens Rzymski pp (92-101).

7 Titus Flavius Clemens (†ok. 212).

${ }^{8}$ Ambrosius Aurelius (333/340-397).
} 
ficiis ministrorum, wzorowanym na stoickim Cyceronie. Wzmianek na te tematy nie brak również u św. Hieronima ze Strydonu9, zwłaszcza w jego Epistolae.

Do prac każdego z tych przykładowo wymienionych autorów mamy obszerną literaturę, która $\mathrm{w}$ różnym stopniu omawia zagadnienia związane $\mathrm{z}$ szeroko rozumianym tematem rodziny, dostępną zwłaszcza w „L'Année Philologique” czy „Vox Patrum”. Nie brakuje też opracowań o charakterze ogólnym, które $\mathrm{z}$ różnych punktów widzenia poruszają tę tematykę. Warto w tym miejscu tytułem przykładu wymienić następujące publikacje: P. Browna, Zmierzch starożytności, w: Historia życia prywatnego, t. 1: Od Cesarstwa Rzymskiego do roku tysięcznego, red. P. Veyne (Wrocław - Warszawa - Kraków 1998); F. Adamskiego, Rodzina między sacrum a profanum (Poznań 1987); J. Carcopina, Życie codzienne w Rzymie w okresie rozkwitu cesarstwa (Warszawa 1960); P. Grimala, Miłość $w$ Rzymie (Warszawa 1990) czy też O. Jurewicza, L. Winniczuk, Starożytni Grecy $i$ Rzymianie w życiu prywatnym i państwowym (Warszawa 1973); L. Winniczuk, Ludzie, zwyczaje i obyczaje starożytnej Grecji i Rzymu (Warszawa 2012); S. Stabryły, Zarys kultury starożytnej Grecji i Rzymu (Warszawa 2007). Godna uwagi jest także książka G. Ceretiego, Matrimonio e indissolubilità (Bologna 1971); M. Kuryłowicza, Prawo i obyczaje w starożytnym Rzymie (Lublin 1994); P. Veyne'a, Cesarstwo Rzymskie, w: Historia życia prywatnego, t. 1: Od Cesarstwa Rzymskiego do roku tysięcznego, red. P. Veyne (Wrocław - Warszawa Kraków 1998). Nie można też nie zauważyć pracy powstałej pod redakcją H. Kowalskiego i M. Kuryłowicza, Contra leges et bonos mores. Przestępstwa obyczajowe w starożytnej Grecji i Rzymie (Lublin 2005).

Gdy chodzi natomiast o literaturę dotyczącą starożytnej rodziny chrześcijańskiej, także tytułem przykładu wymienić należy takie opracowania, jak: Ch.N. Cochrane'a, Chrześcijaństwo i kultura antyczna (Warszawa 1960); E. Dal Covola, Donna e matrimonio alle origini della Chiesa (Roma 1996); M. Simona, Cywilizacja wczesnego chrześcijaństwa (Warszawa 1991). Godna zauważenia jest też książka, która powstała pod redakcją M. Naldiniego, Matrimonio e Familia. Testimonianze dei primi secoli (Fiesole 1996). Nie można też pominąć pracy L. Rossiego, Morale familiare (Bologna 1974), a także R. Cantalamessy, Etica sessuale e matrimonio nel cristianesimo delle origini. Bilancio di una ricerca (Milano 1976).

Spośród prac poruszających zagadnienia moralne związane z życiem małżeńskim i rodzinnym godna uwagi jest publikacja S. Longosza, Prawo rzymskie wobec aborcji, w: Contra leges et bonos mores. Przestęstwa obyczajowe w starożytnej Grecji i Rzymie, red. H. Kowalski, M. Kuryłowicz (Lublin 2005), a także opracowanie pod redakcją F. Drączkowskiego i J. Pałuckiego, Godność chrześcijanina w nauczaniu Ojców Kościoła (Lublin 1996).

\footnotetext{
${ }^{9}$ Sophronius Eusebius Hieronymus Stridonensis (347-419).
} 
Bez wątpienia najwybitniejszym autorem środowiska łacińskiego jest „wielki doktor Kościoła" (magni egregii), biskup Hippony, św. Augustyn ${ }^{10}$, który w swych pismach nie tylko poruszał zagadnienia filozoficzne czy teologiczne, ale także nie pomijał tematyki związanej z małżeństwem, rodzina, kobietą i mężczyzna, żoną i mężem. Także i temu ojcu Kościoła, a zwłaszcza podejmowanej przez niego tematyce związanej z rodziną, poświęcono wiele prac. Mamy na myśli nie tylko książkę A. Hammana, Życie codzienne w Afryce Pótnocnej w czasach św. Augustyna (Warszawa 1989) wprowadzającą w środowisko tego ojca Kościoła, ale także monografie dotyczące małżeństwa i rodziny w nauczaniu św. Augustyna, jak na przykład G. Armasa, La morale de saint Agustin (Roma 1962²); L. Rossiego, Morale familiare (Bologna 1974); L. Pattrina, Il matrimonio secondo Agostino: contratto, sacramento e casi umani (Milano 1995) czy ostatnio wydaną A. Swobody, Kobieta, żona i matka w pismach św. Augustyna (Poznań 2012). Piszący te słowa jest także autorem kilku artykułów poświęconych tym zagadnieniom tak w odniesieniu do starożytności niechrześcijańskiej, jak i do wczesnego chrześcijaństwa, na przykład: Godność męża w pismach Plutarcha z Cheronei i autorów chrześcijańskich IV w. (Augustyn, Ambroży, Hieronim), „Ateneum Kapłańskie” 549-550 (2000), s. 286-298; Rola męża we wspólnocie matżeńskiej $w$ pismach Plutarcha $z$ Cheronei $i$ autorów chrześcijańskich IV w. (s'w. Augustyn, św. Ambroży, św. Hieronim), „Poznańskie Studia Teologiczne" 9 (2000), s. 99-129; Ideat męża w pismach Epikteta i Klemensa Aleksandryjskiego, „Ateneum Kapłańskie” 558 (2002), s. 319-332; Rodzina w pismach Ojców Apostolskich, „Collectanea Theologica” 4 (2002), s. 37-48; Wskazania moralno-pastoralne dla malżonków w pismach św. Augustyna, „Studia Teologiczno-Historyczne Śląska Opolskiego" 24 (2004), s. 295-313.

Gromadząc potrzebne materiały do wspomnianej tu naszej książki, nie pomijaliśmy tych wypowiedzi biskupa z Hippony, które dotyczyły małżonka czy ojca. Stąd też w niniejszej pracy, stosując metodę teologiczną, pragniemy przybliżyć jedynie te poglądy św. Augustyna, które związane są przede wszystkim $\mathrm{z}$ tematem kształtowania samoświadomości moralnej małżonka. W ten sposób będziemy mogli przekonać się, że dla tego autora istotny jest nie tyle wygląd zewnętrzny, zajmowane stanowisko czy status materialny małżonka, ile jego poziom moralny. Stąd też przedmiotem naszego studium będą następujące pisma biskupa Hippony, w których poruszane jest między innymi to zagadnienie: Confessio$n^{11}{ }^{11}$, Contra duas epistolas Pelagianorum ${ }^{12}$, Contra Julianum ${ }^{13}$, De bono co-

${ }^{10}$ Aurelius Augustinus (353-430).

${ }^{11}$ Św. Augustyn, Confessiones, wyd. PL 32, 659-868; CSEL 33, rec. P. Knöll, wyd. pol.: św. Augustyn, Wyznania, thum. Z. Kubiak, Warszawa 1982.

12 Św. Augustyn, Contra duas epistulas Pelagianorum libri quattuor, wyd. PL 44, 549-638; CSEL 60, 423-570.

${ }^{13}$ Św. Augustyn, Contra Julianum libri 6, wyd. PL 44, 641-874, wyd. pol.: św. Augustyn, Przeciw Julianowi, thum. W. Eborowicz, Warszawa 1977, PSP 19, z. 1-2. 
niugali $^{14}$, De bono viduitatis ${ }^{15}$, De civitate De $i^{16}$, De coniugiis adulterinis ${ }^{17}$, De continentia $^{18}$, De diversis quaestionibus LXXXIIII ${ }^{19}$, De Genesi ad litteram ${ }^{20}$, De Genesi ad litteram imperfectus liber ${ }^{21}$, De gratia Christi et de peccato originali ${ }^{22}$, De nuptiis et concupiscenia ${ }^{23}$, De opere monachorum ${ }^{24}$, De sancta virginitate ${ }^{25}$, De sermone Domini in monte $e^{26}$, De utilitate credendi ${ }^{27}$, De vera religione ${ }^{28}$, Enarrationes in Psalmos ${ }^{29}$,

${ }^{14}$ Św. Augustyn, De bono coniugali liber unus, wyd. PL 40, 373-396, CSEL 41, 187-230, rec. I. Zycha, Vindobonae 1900, wyd. pol.: św. Augustyn, Wartości matżeństwa, w: tenże, Antologia pism o matżeństwie i rodzinie, cz. 1, thum. W. Eborowicz, Pelplin 1980, również w: Pisma świętego Augustyna o matżeństwie i dziewictwie, red. A. Eckmann, Lublin 2003, s. 73-116.

${ }^{15}$ Św. Augustyn, De bono viduitatis, wyd. PL 40, 429-450, CSEL 41, 305-343, wyd. pol.: św. Augustyn, O doskonatym wdowieństwie, tłum. T. Gacia, w: Pisma świętego Augustyna o matżénstwie i dziewictwie, dz. cyt., s. 183-222.

${ }^{16}$ Św. Augustyn, De civitate Dei L. XXII, wyd. PL 41, 13-804; CCL 47-48 (1955); CSEL 40, 1-2, wyd. pol.: św. Augustyn, O państwie Bożym, tłum. W. Kornatowski, Warszawa 1977.

${ }^{17}$ Św. Augustyn, De coniugiis adulterinis libri duo, wyd. PL 40, 451-486, CSEL 41, 347-410, wyd. pol.: św. Augustyn, Cudzołożne matżeństwa, thum. M. Damian (Księga I), M. Cieśluk (Księga II), w: Pisma świętego Augustyna o matżeństwie i dziewictwie, dz. cyt., s. 223-259.

18 Św. Augustyn, De continentia liber unus, wyd. PL 40, 349-372, CSEL 41, 141-183; wyd. pol.: św. Augustyn, O powściagliwości, tłum. S. Laskowski, w: Pisma świętego Augustyna o matżeństwie i dziewictwie, dz. cyt., s. 343-390.

${ }^{19}$ Św. Augustyn, De diversis quaestionibus octoginta tribus liber unus, wyd. PL 40, 11-100; CCL 44A, 11-249.

${ }^{20}$ Tenże, De Genesi ad litteram libri duodecim, wyd. PL 34, 245-485; CSEL 28, I, wyd. pol.: tenże, Komentarz słowny do księgi Rodzaju, tłum. J. Sulowski, w: św. Augustyn, Pisma egzegetyczne przeciw manichejczykom, Warszawa 1980, PSP 25.

${ }^{21}$ Tenże, De Genesi ad litteram imperfectus liber, wyd. PL 34, 219-246; CSEL 28, I, wyd. pol.: tenże, Niedokończony komentarz słowny do Księgi Rodzaju, tłum. J. Sulowski, w: św. Augustyn, Pisma egzegetyczne przeciw manichejczykom, dz. cyt., PSP 25.

${ }_{22}^{22}$ Tenże, De gratia Christi et de peccato originali, wyd. PL 44, 359-410; CSEL 42, 125-260.

${ }^{23}$ Tenże, De nuptiis et concupiscentia ad Valerium libri duo, wyd. PL 44, 413-474, CSEL 42, 211-319, wyd. pol.: św. Augustyn, Matżeństwo i pożqdliwość, Księga 1, thum. K. Kościelniak, w: Pisma świętego Augustyna o matżeństwie i dziewictwie, dz. cyt., s. 343-390.

${ }^{24}$ Św. Augustyn, De opere monachorum, wyd. PL 40, 547-558, J. Zycha, CSEL 41, 1900, 531 -595, wyd. pol.: św. Augustyn, O pracy mnichów, thum. R. Szaszka, w: tenże, Pisma monastyczne, Kraków 2002, Źródła Monastyczne, t. 27, s. 185-267.

${ }^{25}$ Św. Augustyn, De sancta virginitate, wyd. PL 40, 397-428, J. Zycha, CSEL 41, 1900, 235 -302, wyd. pol.: O świętym dziewictwie, w: Pisma świętego Augustyna o matżeństwie i dziewictwie, thum. R. Bobel (1.1-30.30), H. Bojko (31.31-56.57), Lublin 2003, s. 117-182.

${ }^{26}$ Św. Augustyn, De sermone Domini in monte libri duo, wyd. CSEL 35, Pars VII, 2, Aurelii Augustini Opera, wyd. pol.: św. Augustyn, O kazaniu Pana na górze, thum. S. Ryznar, J. Sulowski, PSP 48.

${ }^{27}$ Św. Augustyn, De utilitate credendi, wyd. J. Zycha, CSEL 25, s. 1-48, Wiedeń 1891, wyd. pol.: św. Augustyn, O pożytku wiary, thum. J. Sulowski, Warszawa 1990, t. 54, PSP.

${ }^{28}$ Tenże, De vera religione, wyd. PL 34, 121-172; CSEL 77, rec. G. Green, wyd. pol.: św. Augustyn, O wierze prawdziwej, tłum. J. Ptaszyński, w: tenże, Dialogi i pisma filozoficzne, t. IV, Warszawa 1954.

${ }^{29}$ Św. Augustyn, Enarrationes in Psalmos, wyd. PL 66-1900; CC 38-40, ed. E. Dekkers, J. Freipont, wyd. pol.: Objaśnienia Psalmów, Ps. 1-36; t. XXXVII: Ps. 36-57, t. XXXVIII; Ps. 58-77, 
Epistolae $^{30}$, Expositio Epistolae ad Galatas ${ }^{31}$, In epistolam Joannis ad Parthos ${ }^{32}$, In Joannis Evangelium Tractatus ${ }^{33}$, Quaestiones in Heptateuchum ${ }^{34}$, Retractatio$n^{35} \mathrm{~s}^{35}$, Sermones ${ }^{36}$.

Całość opracowania składać się będzie z następujących paragrafów. W pierwszym postaramy się przedstawić przeprowadzoną przez św. Augustyna charakterystykę małżonka. Ukażemy więc wpierw jego przemyślenia na temat wyglądu zewnętrznego, a następnie na temat przymiotów osobistych mężczyzny.

Drugi paragraf poświęcony zostanie zagadnieniu pracy nad sobą, która obejmuje między innymi troskę o dobroć moralną, a zwłaszcza o cnotę czystości i wstrzemięźliwości. Paragraf ten przedstawia również poglądy św. Augustyna na temat pożądliwości i proponowane przez niego sposoby przezwyciężania jej oraz jego zachęty do utrzymywania cnoty.

Na końcu zamieścimy stosowne wnioski.

\section{Charakterystyka małżonka}

\section{Wygląd zewnętrzny}

Święty Augustyn był przekonany o tym, że pod względem fizycznym mężczyzna jest silniejszy od kobiety ${ }^{37}$, zalecał także, by małżonki nie oceniały swych

t. XXXIX; Ps. 78-102, t. XL; Ps. 103-123, t. XLI, Ps. 124-150, tłum. J. Sulowski, t. XLII, z. 1: Indeksy, Warszawa 1986, t. XLII, z. 2. PSP.

${ }^{30}$ Św. Augustyn, Epistolae, wyd. PL 33, 61-1094; Augustinus Aurelius, Opera. Sect. 2, pars 6: Epistolae ex duobus codicibus nuper in lucem prolatae, rec. J. Divjak, Vindobonae 1981; wyd. pol.: św. Augustyn, Listy [1-75], thum. W. Eborowicz, Pelplin 1991. Pozostałe listy cytuję w przekładzie własnym.

${ }^{31}$ Św. Augustyn, Expositio Epistolae ad Galatas, wyd. PL 35, 2105-2148; CSEL 84 (1971) 55-141, rec. J. Divjak.

32 Św. Augustyn, In Epistolam Joannis ad Parthos Tractatus Decem, vol. 35, col. 1977-2061; SCh 75, wyd. pol.: św. Augustyn, Homilie na Ewangelie i pierwszy list Św. Jana, thum. W. Szołdrski, W. Kania, Warszawa 1977, PSP 15.

33 Św. Augustyn, In Joannis Evangelium. Tractatus CXXIV, wyd. CC 36 Turnhout 1954; PL 35 1379-1976; wyd. pol.: św. Augustyn, Homilie na Ewangelie i pierwszy list św. Jana, thum. W. Szołdrski, Warszawa 1977, PSP 40, t. 1-2.

${ }^{34}$ Św. Augustyn, Quaestiones in Heptateuchum libri VII, wyd. PL 34, 547-824; J. Zycha CSEL 28/2 (1895), 1-506; J. Fraipont, CCL 33 (1958), s. 1-377; wyd. pol.: św. Augustyn, Problemy Heptateuchu, cz. 1, thum. J. Sulowski, Warszawa 1990, t. 46; cz. 2, Warszawa 1990, t. 47, PSP.

${ }_{35}$ Św. Augustyn, Retractationes, wyd. PL 32, 583-656; rec. P. Knöll, CSEL 36, Vindobonae Lipsiae 1902, wyd. pol.: św. Augustyn, Sprostowania, tłum. J. Sulowski, Warszawa 1979, PSP 22.

${ }^{36}$ Św. Augustyn, Sermones, wyd. PL 38, 23-1483; 39, 1493-1638; św. Augustyn, Wybór mów: kazania świateczne i okolicznościowe, wyd. pol. J. Jaworski, Warszawa 1973, PSP 12. Mowy znajdujące się poza tym zbiorem cytuję w przekładzie własnym.

${ }^{37}$ D. Covi, Il fondamento ontologico della sessualità umana secondo S. Agostino, „Laurentianum” 11 (1970), s. 382. 
mężów, zwracając uwagę tylko na ich urodę zewnętrznąa ${ }^{38}$ Ta refleksja biskupa Hippony została, naszym zdaniem, bardziej pogłębiona i rozwinięta $\mathrm{w}$ innym miejscu, w którym zastanawiał się, co czyni brzydki mężczyzna kochający piękną pannę, a także, co czyni brzydka panna kochająca przystojnego mężczyznę. Próbował też odpowiedzieć na pytanie, czy miłość może uczynić kobietę piękną a mężczyznę przystojnym ${ }^{39}$.

Nim jednak udzielił odpowiedzi, zauważył, że brzydki mężczyzna, który kocha piękną kobietę, przeglądając się w zwierciadle, musi się rumienić, zwłaszcza gdy porówna się z ukochaną. Wobec tego św. Augustyn postawił kolejne pytanie, czy taki mężczyzna ma czekać, aż stanie się kiedyś piękny. W związku z tym zauważył, że gdyby tak postapił, to prędzej doczekałby starości, która uczyni go jeszcze brzydszym. Doradził więc, by przestał kochać tę kobietę i myśleć o małżeństwie z nią. Jeśli jednak koniecznie chce wprowadzić ją jako żonę do domu, to winien kochać w niej czystość, a nie zewnętrzne piękno ciała ${ }^{40}$.

Jest to komentarz do informacji pochodzących z przekazów lekarza Soranusa z Efezu (I w.). Mamy tu na myśli dwie wzajemnie się uzupełniające wypowiedzi św. Augustyna. Jedna pochodzi z dzieła Contra Julianum, gdzie omawiany ojciec Kościoła na podstawie wiadomości zaczerpniętych od tego lekarza przytacza pewną anegdotę na temat niezbyt urodziwego tyrana Dionizjosa Starszego (430-367 a. Chr.) z Syrakuz, który nie chciał, by żona urodziła mu brzydkie dzieci, wobec czego w czasie stosunku ze swą żoną stawiał przed nią piękne malowidło $^{41}$. Druga zaś zawarta jest w Retractationes i dotyczy tego samego tematu $\mathrm{z}$ tym, że autor, przyznając się do słabej pamięci, przypisuje to postępowanie bliżej nieznanemu z imienia królowi Cypru ${ }^{42}$. W swym komentarzu podkreśla, że Bóg, stwarzając natury, zachowuje prawa, które kierują ich poruszeniami. Wady natomiast, chociaż jako przypadłości tkwią w podmiocie, to jednak przechodzą

${ }^{38}$ Św. Augustyn, De nuptiis et concupiscentia, I, 13, 15, PL 44, 422-423. Por. J. Peters, Die Ehe nach der Lehre des hl. Augustinus, Paderborn 1918, s. 24.

39 Św. Augustyn, In epistolam Joannis ad Parthos tractatus decem, 9, 9; PL 35, 2051-2052.

${ }^{40}$ Tenże, In epistolam Joannis ad Parthos tractatus decem, 9, 9; PL 35, 2051-2052.

${ }^{41}$ Tenże, Contra Julianum, V, 14, 51; PL 44, 814: ,[...] Soranus medicinae auctor nobilissimus scribit, et exemplo confirmat historiae. Nam Dionysium tyrannum narrat, eo quod ipse deformis esset, nec tales habere filios vellet, uxori suae in concubitu formosam proponere solere picturam, cuius pulchritudinem concupiscendo quodam modo raperet, et in prolem quam concipiebat afficiendo transmitteret [...]".

${ }^{42}$ Tenże, Retractationes, II, 62; PL 32, 655: ,[...] nomen hominis qui hoc facere solebat, quasi certum posui, cum sit incertum, quia memoria me fefellit. Hoc autem Soranus auctor medicinae scripsit regem Cyprium facere solere, sed nomen eius proprium non expressit". W tym miejscu należy także wspomnieć podobną sytuację opisaną w Quaestiones in Heptateuchum, I, 93; PL 34, 572, gdzie biskup Hippony odwołuje się do decyzji lekarza Hippokratesa z Kos (ok. 460-377 przed Chr.), który uratował od kary kobietę, która urodziła piękne dziecko niepodobne ani do niej, ani do męża, ponieważ podczas stosunku spoglądała na wiszący w pomieszczeniu obraz. 
z rodziców na synów, jednak nie drogą zewnętrznego przekazywania z jednego przedmiotu na drugi, gdyż jest to niemożliwe ${ }^{43}$.

\section{Przymioty osobiste}

Lektura pism biskupa Hippony przynosi nam jednak o wiele więcej informacji na temat przymiotów osobistych mężczyzny i małżonka, aniżeli dotyczących jego wyglądu zewnętrznego. Augustyn podkreśla, że nie chodzi tylko o to, iż mężczyzna kieruje się w swym postępowaniu przede wszystkim kalkulacją rozumową ${ }^{44}$, że winien być mądrym przywódcą rodziny, na co zwracano na przykład uwagę w okresie augustowskim ${ }^{45}$, ale stara się pogłębić swoje obserwacje, udzielając wskazań odnoszących się tak do jego udziału w życiu publicznym, jak i prywatnym ${ }^{46}$.

Wypowiadając się na temat przymiotów osobistych mężczyzny, zauważa nie tylko, że „wielu mężów wybitnych i godnych zajmowało się filozofią, żyjąc w stanie małżeńskim"47, ale także podkreśla znaczenie ich kultury osobistej. Potwierdza to na przykład Adalbert G. Hamman, który stwierdza, że biskup Hippony zwłaszcza w swych listach wyrażał się pochwalnie o szefie gabinetu cesarza, Marcellinusie; twierdził, że był to człowiek wielkiej kultury, ekspert w dziedzinie Pisma Świętego, wzorowy ojciec rodziny i święty. Przewodniczył też konferencji w Kartaginie w 411 roku $^{48}$, co - naszym zdaniem - może świadczyć również o zaangażowaniu społecznym tego mężczyzny ${ }^{49}$.

Zdaniem naszego autora, na pochwałę zasługiwały także otwartość i uczuciowość. Człowiekiem obdarzonym takimi przymiotami był ojciec przyszłego

${ }^{43}$ Św. Augustyn, Contra Julianum, V, 14, 51; PL 44, 813.

${ }^{44}$ A. Milewska, Monika jako ideat matki i żony przedstawiony w „Wyznaniach” Św. Augustyna, Bydgoszcz 1999, s. 232.

${ }^{45} \mathrm{~W}$ literaturze przyjmuje się, że ten okres obejmował lata 31 przed Chr.-14 po Chr. Por. J. Jundziłł, Typy matzeństw a wychowanie dziecka $w$ rodzinie rzymskiej, w: Rodzina $w$ starożytnym Rzymie, red. tenże, Bydgoszcz 1993, s. 78. M. Cytowska, H. Szelest, Literatura rzymska. Okres augustowski, Warszawa 1990; S. Stabryła, Historia literatury starożytnej Grecji i Rzymu, Wrocław - Warszawa - Kraków 2002, s. 358-415.

${ }^{46}$ Św. Augustyn, In epistolam Joannis ad Parthos tractatus decem, 8, 1; PL 35, 2036.

${ }^{47}$ Tenże, Confessiones, VI, 11, 19, PL 32, 729: „Multi magni viri et imitatione dignissimi, sapientiae studio cum coniugibus dediti fuerunt”. Por. G. Bardy, Święty Augustyn. Człowiek i dzieto, Warszawa 1955, s. 79.

${ }^{48}$ Tytułem przykładu można wymienić takie listy św. Augustyna, jak: Epistolae, 133 PL 33, 509; 134 PL 33, 511; 138 PL 33, 525; 139 PL 33, 535; 143 PL 33, 585; 166 PL 33, 720; 169 PL 33, 742; Por. G.A. Hamman, Życie codzienne w Afryce Pótnocnej w czasach św. Augustyna, Warszawa 1989, s. 223. Na temat tej konferencji por. Acta Synodalia ann. 381-431, w: Synodi et Collectiones Legum, Kraków 2010, ŹMT 52, red. A. Baron, H. Pietras, vol. IV, s. 185*-192*.

${ }^{49}$ A.G. Hamman, Życie codzienne..., dz. cyt. s. 100-101; J. Jundziłl, Typy matżeństw..., dz. cyt., s. $74-75$. 
biskupa Hippony ${ }^{50}$, który, jak możemy się przekonać, starał się pozytywnie ocenić jego dobre serce ${ }^{51}$ i posłuszeństwo okazywane matce ${ }^{52}$.

We wspomnianej pracy A.G. Hamman charakteryzuje ojca św. Augustyna jako człowieka nieśmiałego, a cecha ta była - jego zdaniem - spowodowana ubóstwem materialnym. Wskutek tego krępował się występować publicznie, a także witać swego patrona ${ }^{53}$. Mimo to był na tyle ambitny, że postanowił wysłać swego syna na dalsze studia do Kartaginy ${ }^{54}$.

Zdaniem biskupa Hippony, małżonek winien odznaczać się także umiarkowaniem i skromnością w mowie i milczeniu, w pracy i w spoczynku ${ }^{55}$. Myśl tę uzupełnia stwierdzenie, że żony nie powinny kochać mężów dlatego, że pochodzą oni ze szlachetnego rodu (genere nobiles), są bogaci (divites), ambitni (sublimes), ciałem godni miłości (carne amabiles), ale że są oni skromni (pudici) i dobrzy $(\text { boni })^{56}$. Przykładem jest Pinianus, mąż Melanii Młodszej, który pragnąc wieść życie doskonałe, wyzbył się swych dóbr materialnych ${ }^{57}$.

Przytoczone w tym paragrafie przykłady postępowania mężczyzny i małżonka wskazują w naszym przekonaniu przede wszystkim na fundamentalne znaczenie miłości w życiu człowieka. Analizując treść przykazania miłości Boga i bliźniego (Mt 22,35-40; Mk 12,28-31; Łk 10,25-27; Pwt 6,5; Kpł 19,18), nasz autor formułuje klasyczną doktrynę o porządku miłości. Zauważa bowiem, że w tym przykazaniu człowiek znajduje trzy przedmioty miłości, a mianowicie miłość Boga, siebie samego i bliźniego. Zdaniem autora, ten, kto miłuje Boga, nie popełnia błędu, miłując siebie samego. Oznacza to więc, że człowiek winien pomagać w miłowaniu Boga bliźniemu, którego z kolei winien kochać jak siebie samego. Stąd też mąż i ojciec powinien świadczyć pomoc żonie, dzieciom, swym domownikom oraz w miarę możliwości innym ludziom, spodziewając się, w razie potrzeby, takiej pomocy od bliźniego dla siebie. Dzięki temu będzie zachowywał pokój z każdym człowiekiem, co polega na praktykowaniu uporządkowanej zgody, a więc nieszkodzeniu nikomu i pomaganiu zawsze, gdy jest to

${ }^{50}$ A. Trapè, Święty Augustyn. Człowiek duszpasterz mistyk, Warszawa 1987, s. 24.

${ }^{51}$ Św. Augustyn, Confessiones, IX, 9, 19, PL 32, 772. Por. G. Bardy, Święty Augustyn..., dz. cyt., s. 30.

${ }_{52}$ Św. Augustyn, Confessiones, IX, 9, 20; PL 32, 773. Por. E. Giannarelli, La donna nella famiglia cristiana secondo i Padri, w: AA. VV., Matrimonio e famiglia. Testimonianze dei primi secoli, red. M. Naldini, Fiesole 1996, s. 169.

${ }^{53}$ G.A. Hamman, Życie codzienne..., dz. cyt., s. 100.

${ }^{54}$ Św. Augustyn, Confessiones, II, 3, 5; PL 32, 677: ,[...] animositate magis quam opibus patris [...]". Por. Ch.N. Cochrane, Chrześcijaństwo i kultura antyczna, Warszawa 1960, s. 379.

${ }_{55}$ Św. Augustyn, In epistolam Joannis ad Parthos tractatus decem, 8, 1; PL 35, 2036.

${ }^{56}$ Tenże, De nuptiis et concupiscentia, I, 13, 15; PL 44, 423. Por. J. Peters, Die Ehe nach der Lehre..., dz. cyt., s. 24.

${ }^{57}$ Św. Augustyn, Epistolae, 124, 1-2; PL 33, 471-473. Por. G. Bardy, Święty Augustyn ..., dz. cyt., s. 245; G.A. Hamman, Życie codzienne..., dz. cyt., s. 353, 355. 
możliwe ${ }^{58}$. Pierwszą więc, zdaniem autora, powinnością małżonka jest troska o swych najbliższych, „gdyż do ich wspomagania ma człowiek dogodniejszą i łatwiejszą sposobność wynikającą z naturalnego porządku lub z samego złączenia w ludzką społeczność" 59 .

Do zachowania właściwej hierarchii wartości potrzebny jest także odpowiedni stosunek do dóbr materialnych. Nie dziwi więc, że św. Augustyn pochwalał u mężczyzn cnotę ubóstwa (paupertas) ${ }^{60}$ oraz troskę o biednych ${ }^{61}$.

Lektura pism naszego autora pozwala również zauważyć, że dobry małżonek nie tylko, jak pewien starzec o imieniu Florencjusz, troszczy się o siebie samego ${ }^{62}$, lecz także nie zaniedbuje starania o swych najbliższych. Biskup Hippony bowiem, opierając się na nauczaniu św. Pawła (1 Kor 7,33), stwierdza, że ten, kto wstapił w związek małżeński, zabiega o sprawy świata, o to, jak się przypodobać żonie ${ }^{63}$. Myśl tę uzupełnia kolejna wypowiedź, w której św. Augustyn pochwala postawę mężczyzny, który dba o swój dom. Wyrazem tego jest zarówno podejmowana przez niego praca, z której często powraca zmęczony późno do domu $^{64}$, jak i życzliwa ${ }^{65}$ troska o dom zbudowany własnym wysiłkiem oraz jego najbliższe otoczenie ${ }^{66}$, w którym pragnie $\mathrm{z}$ radością przebywać i odpoczywać po pracy ${ }^{67}$. Ta myśl obecna jest także $\mathrm{w}$ innych pismach naszego autora. Zauważa on bowiem, że żonaty mężczyzna, zwłaszcza gdy przebywa daleko od domu, nie przestaje się interesować dobrem żony i swych dzieci, a zwłaszcza ich stanem zdrowia oraz tym, co czynią podczas jego nieobecności ${ }^{68}$.

${ }^{58}$ Św. Augustyn, De civitate Dei, XIX, 14; PL 41, 643: ,[...] id est ordinata concordia: cuius hic ordo est, primum ut nulli noceat, deinde ut etiam prosit cui potuerit".

${ }^{59}$ Tenże, De civitate Dei, XIX, 14; PL 41, 643: „Primitus ergo inest ei suorum cura: ad eos quippe habet opportuniorem facilioremque aditum consulendi, vel naturae ordine, vel ipsius societatis humanae”. Por. G. Armas, Hacia una ética agustiniana del hogar, „Augustinus” 3 (1958), s. 473.

${ }^{60}$ Św. Augustyn, Enarrationes in Psalmos, 40, 5; PL 36, 458.

${ }^{61}$ Tenże, De sermone Domini in monte, II, 2, 7; PL 34, 1272; tenże, In epistolam Joannis ad Parthos tractatus decem, 8, 1; PL 35, 2036.

${ }^{62}$ Tenże, De civitate Dei, XXII, 8, 9; PL 41, 766.

${ }^{63}$ Tenże, De sancta virginitate, 22, 22; PL 40, 407.

${ }^{64}$ Tenże, Enarrationes in Psalmos, 40, 5; PL 36, 458. Por. G. Armas, Hacia una ética agustiniana del hogar. Amor de la esposa al marido, „Augustinus” 4 (1959), s. 527; G.A. Hamman, $\dot{Z} y$ cie codzienne..., dz. cyt., s. 101.

${ }^{65}$ Św. Augustyn, In epistolam Joannis ad Parthos tractatus decem, 8, 1; PL 35, 2036.

${ }^{66}$ Tenże, Enarrationes in Psalmos, 40, 5; PL 36, 458: „[...] acquiescit [...] in praediolo suo, in novella manibus suis consita, in aedificio aliquo suo studio fabricato [...]".

${ }^{67}$ Tenże, Enarrationes in Psalmos, 35, 5; PL 36, 344: ,[...] quomodo quisque fatigatus negotiis foris, currit ad domum suam ut ibi requiescat, et dat operam cito finire negotia quae foris sunt, et tollere se ad requiem in domum suam”. Por. N. Blázquez, Feminismo agustiniano, „Augustinus” 27 (1982), s. 51.

${ }^{68}$ Św. Augustyn, De utilitate credendi, 9, 22; PL 42, 80: ,[...] ad hominem pertinere coniugem ac liberos et eorum salutem; si quispiam peregre positus, quemadmodum valeant ac sese agant sua conjux ac liberi, omnes advenientes sedulo percontetur, magna utique ducitur cupiditate no- 
Święty Augustyn pochwalał również troskę męża o utrzymanie należytego pokoju w domu, czego przykładem może być postępowanie Patrycjusza, ojca przyszłego biskupa Hippony, który posłuszny swej matce, dbał o dyscyplinę i dobre stosunki rodzinne, nie wahał się więc stosować nawet chłosty wobec winnych jego zakłócenia ${ }^{69}$. Nasz autor przestrzegał przed dominacją żony nad mężem. Taki pokój nazywał przewrotnym (pax perversa). Właściwą relacją jest, zdaniem autora, podporządkowanie żony mężowi, co rodzi prawy pokój (pax recta $)^{70}$. Myśl ta kontynuowana jest także w innym miejscu, gdzie nasz autor uczył, że rozkazują ci, którzy troszczą się o innych. Tak czyni mąż wobec żony, rozkazują rodzice dzieciom, panowie sługom. Słuchają z kolei ci, którzy są przedmiotem troski: żony mężów, dzieci rodziców, słudzy swych panów. Kontynuując tę myśl na podstawie Pisma Świętego, zaznaczył, że w domu człowieka sprawiedliwego żyjącego z wiary (Ha 2,4; Ga 3,11), a będącego jeszcze daleko od państwa niebieskiego, ci, którzy rozkazują, w istocie służą tym, którym wydają rozkazy (Łk 22,26-27; J 13,16-17). Rozkazują nie z żądzy panowania, ale z obowiązku pomagania, nie $\mathrm{z}$ władczej wyniosłości, ale z powodu pieczołowitości ${ }^{71}$. Warunkiem jednak istnienia takiego właśnie pokoju jest, jak czytamy w innym miejscu, podporządkowanie się z kolei męża, jak możemy domyślać się z kontekstu, $\mathrm{Bogu}^{72}$. Te refleksje uzupełnia zachęta, by mężowie nie tylko miłowali swe żony, dzieci, służbę i przyjaciół, ale pragnęli przebywania przy nich i czynili wszystko, by podczas zajęć domowych panował pokój ${ }^{73}$.

Święty Augustyn był przekonany, że tak rozumiane i stosowane przykazanie miłości Boga, siebie samego i bliźniego oraz troska o pokój w domu wpływają na relacje panujące w państwie. Potwierdza to jego wypowiedź, z której wynika, że dom człowieka winien być zaczątkiem lub cząstką państwa ${ }^{74}$, ponieważ od tego, czy w nim panuje pokój, zależy pokój państwa. W ten sposób „uporządkowana zgoda domowników co do rozkazywania i posłuchu, zmierza do uporządkowanej zgody obywateli co do rozkazywania i posłuchu" ${ }^{\text {"75 }}$. Wobec tego ojciec

scendi [...]"; tenże, Sermo, 51, 21; PL 38, 345. Por. G. Armas, Hacia una ética agustiniana del hogar, „Augustinus” 3 (1958), s. 473.

${ }^{69}$ Św. Augustyn, Confessiones, IX, 9, 20; PL 32, 773; por. G. Bardy, Święty Augustyn..., dz. cyt., s. 31; E. Giannarelli, La donna nella famiglia..., dz. cyt., s. 169.

${ }^{70}$ Św. Augustyn, Enarrationes in Psalmos, 143, 6; PL 37, 1860; tenże, De vera religione, 41, 78; PL 34, 157. Por. N. Blázquez, Feminismo..., dz. cyt., s. 9.

${ }^{71}$ Św. Augustyn, De civitate Dei, XIX, 14; PL 41, 642-643. Por. G. Armas, Hacia una ética agustiniana del hogar, "Augustinus" 3 (1958), s. 473.

72 Św. Augustyn, Enarrationes in Psalmos, 143, 6; PL 37, 1860.

${ }^{73}$ Tenże, Enarrationes in Psalmos, 147, 15; PL 37, 1924: „Hanc quam nominatam sic amatis et diligitis, ipsam sectamini, ipsam desiderate; ipsam in domo, ipsam in negotio, ipsam in uxoribus, ipsam in filiis, ipsam in servis, ipsam in amicis, ipsam in inimicis diligite".

${ }^{74}$ Tenże, De civitate Dei, XIX, 16; PL 41, 645: „Quia igitur hominis domus initium sive particula debet esse civitatis [...]".

${ }^{75}$ Tenże, De civitate Dei, XIX, 16; PL 41, 645: „,...] omne autem initium ad aliquem sui ge- 
rodziny winien z prawa uznanego przez państwo czerpać zasady, według których „kierować ma swym domem tak, iżby ten zostawał w zgodzie z pokojem tegoż państwa"76. Nasz autor chwali chrześcijańską postawę wielu mężów, żon, dzieci, wyrażającą się tym, że nie są oni wrogami państwa ${ }^{77}$.

Wśród przymiotów osobistych mężczyzny wymieniona została także poko$\mathrm{ra}^{78}$ oraz bezinteresowna miłość nie tylko do własnej małżonki ${ }^{79}$, ale przede wszystkim do ojczyzny.

Biskup Hippony przypomniał też, że ojciec i mąż winien wzbudzać zarówno lęk, jak i miłość ${ }^{80}$. Dobry mąż nie tylko darzy miłością, ale poprzez swoje postępowanie zachęca do tego, by być miłowanym.

\section{Praca nad sobą}

\section{Troska o dobro moralne}

Analizując nauczanie św. Augustyna dotyczące małżonka, możemy przekonać się, że podkreślał on również konieczność pracy nad sobą. Wskazuje na to jego stwierdzenie, że ozdobą chrześcijan i chrześcijanek są między innymi „dobre obyczaje"81. Myśl tę nasz autor pogłębia w innym miejscu, pisząc, że żona powinna kochać swego męża między innymi za to, że jest on dobrym człowiekiem $^{82}$. Hamman zwraca uwagę na to, że świadectwem tego, iż często tak było, są zachowane stele i nagrobne epitafia upamiętniające drogich i pełnych godności mężów ${ }^{83}$.

Z kolejnych wypowiedzi biskupa Hippony wynika, że chodzi tu przede wszystkim o dobro w znaczeniu moralnym. Przykładem jest jedna z Mów św.

neris finem, et omnis pars ad universi, cuius pars est, integritatem refertur: satis apparet esse consequens, ut ad pacem civicam pax domestica referatur, id est, ut ordinata imperandi obediendique concordia cohabitantium referatur ad ordinatam imperandi obediendique concordiam civium".

${ }^{76}$ Tenże, De civitate Dei, XIX, 16; PL 41, 645: „Ita fit, ut ex lege civitatis praecepta sumere patremfamilias oporteat, quibus domum suam sic regat, ut sit paci accommodata civitatis". W naszym przekonaniu jest to możliwe pod warunkiem, że prawodawstwo państwowe pozostaje w zgodzie z prawem Bożym.

77 Św. Augustyn, Epistolae, 138, 2, 15; PL 33, 532: „,...] non dubitent eam confiteri magnam, si obtemperetur, salutem esse reipublicae”. Por. A. Trapè, Święty Augustyn ..., dz. cyt., s. 228.

${ }^{78}$ Tenże, De sancta virginitate, 51, 52; PL 40, 426.

79 Tenże, Enarrationes in Psalmos, 55, 17; PL 36, 658. Por. A. Trapè, Święty Augustyn..., dz. cyt., s. 291.

${ }^{80}$ Św. Augustyn, Enarrationes in Psalmos, 118, (31) 3; PL 37, 1592.

${ }^{81}$ Tenże, Epistolae, 245, 1; PL 33, 1060: „Nam verus ornatus maxime Christianorum et Christianarum $[\ldots]$ mores boni sunt".

${ }^{82}$ Tenże, De nuptiis et concupiscentia, I, 13, 15, PL 44, 422-423. Por. J. Peters, Die Ehe nach der Lehre..., dz. cyt., s. 24.

${ }^{83}$ G.A. Hamman, Życie codzienne..., dz. cyt., s. 87. 
Augustyna, który w kontekście nauki o związku Kościoła z Chrystusem, Oblubienicy z Oblubieńcem, zauważa, że Głowa musi mieć godne siebie ciało. Wypowiadając te słowa, autor pośrednio wskazuje na to, że skoro tak wielki Mąż (Chrystus) musi mieć godną siebie Małżonkę (Kościół), to analogiczna relacja musi zachodzić także pomiędzy mężem i żoną ${ }^{84}$. Dzieląc się tymi przemyśleniami, św. Augustyn zdawał sobie sprawę z tego, ,że dobra żona może być pod władzą męża dobrego, zła żona pod władzą złego lub dobrego, dobra pod władzą złego" ${ }^{85}$. Z tego więc powodu zachęcał na przykład adresata listu, Bonifacjusza, by będąc mężem, unikał zła, na co zwracano uwagę także w starożytności niechrześcijańskieje ${ }^{86}$ a za popełnione, czynił pokutę ${ }^{87}$. Stąd w innym miejscu, wykorzystując grę słów (vir/virilis), uczył, że godność mężczyzny nie polega na „swobodzie grzeszenia”"8. Podobną myśl zawarł także w jednym z listów, gdzie podkreślił, że przedstawicielka słabszej płci nie może być silniejsza od mężczyzny (vir), który winien charakteryzować się cnotami (virtutes) ${ }^{89}$.

Dzieląc się tymi przemyśleniami, nie tylko zachęcał do unikania zła, ale także wskazywał kierunki i pola pracy nad sobą. Przypominał, że mąż winien starać się wypracować cnoty ${ }^{90}$, których będzie przykładem dla swej żony ${ }^{91}$. Przewyższając ją nawet $\mathrm{w}$ posiadanych cnotach $^{92}$, stanie się dla niej duchowym wsparciem $^{93}$ i przewodnikiem $(d u x)^{94}$, którego będzie starała się naśladować ${ }^{95}$. Ponieważ wszystkie cnoty, jak czytamy, „także te, których narzędziem jest ciało, maja swe siedlisko w duszy", stąd też, jak wynika to z postawionego przez niego pytania, nie można uważać ciała za czyste, skoro „duch dopuszcza się nierządu (fornicatur) wobec Boga" ${ }^{" 96}$. Myśl ta obecna jest także w innej wypowiedzi, w której

${ }^{84}$ Św. Augustyn, Sermones, 341, 11, 13; PL 39, 1500.

${ }^{85}$ Tenże, Contra Julianum, VI, 20, 64, PL 44, 862: „Nonne uxor subditur viro, et bono bona, et malo mala, et bono mala, et malo bona?"

${ }^{86}$ J. Jundziłł, Typy matżeństw..., dz. cyt., s. 78.

${ }^{87}$ Św. Augustyn, Epistolae, 220, 5; PL 33, 994.

${ }^{88}$ Tenże, De coniugiis adulterinis, II, 20, 22; PL 40, 486: „Unde istos qui virilem excellentiam non putant nisi peccandi licentiam [...]".

${ }^{89}$ Tenże, Epistolae, 127, 9, PL 33, 487.

${ }^{90}$ Tenże, Sermones, 332, 4; PL 38, 1463. Por. L. Anné, La conclusion du mariage dans la tradition et le droit de l'Église Latine jusqu'au VI siècle, „Ephemerides Theologicae Lovanienses" 12 (1935), s. 522.

${ }^{91}$ Św. Augustyn, De coniugiis adulterinis, II, 8, 7; PL 40, 475. Por. A. Eckmann, Wprowadzenie, w: Pisma świętego Augustyna o matzeństwie i dziewictwie, dz. cyt., s. 30.

${ }_{92}$ Św. Augustyn, Sermones, 9, 3, 3, PL 38, 77: ,[...] et cum debeas in virtute praecedere uxorem [...]”. Por. L. Anné, La conclusion du mariage..., dz. cyt., s. 522.

${ }_{93}$ J. Jundziłl, Ideat żony i matki w „Wyznaniach” św. Augustyna a klasyczne wzorce rzymskie, „Vox Patrum” 15 (1988), s. 825.

${ }^{94}$ Św. Augustyn, De coniugiis adulterinis, II, 8, 7; PL 40, 475.

95 Tenże, Sermones, 9, 3, 3, PL 38, 77.

${ }^{96}$ Tenże, De nuptiis et concupiscentia, I, 4, 5; PL 44, 416: „Cum enim virtus sit pudicitia, cui vitium contrarium est impudicitia, omnesque virtutes etiam quae per corpus operantur, in animo 
Augustyn podał przykład postępowania pewnego mężczyzny, który, jak czytamy, darzył swych rodziców należną czcią, zachowywał czystość (castitas) i wstrzemięźliwość (continentiam) od pożycia małżeńskiego, ale nie zachował poprawnej wiary katolickiej. Taki człowiek, jak zauważył św. Augustyn, zostanie po tym życiu potępiony ${ }^{97}$.

W świetle tych wypowiedzi rodzi się więc pytanie, jakie cnoty mężczyzny szczególnie chwalił interesujący nas tutaj ojciec Kościoła.

\subsection{Troska o cnotę czystości}

Lektura jego pism pokazuje, że bardzo bliska mu była cnota czystości małżeńskiej. Zaliczał ją do darów Bożych ${ }^{98}$, które przybliżają człowieka do Niego ${ }^{99}$. $\mathrm{W}$ jego przekonaniu pomaga ona w utrzymaniu dyscypliny w pożyciu małżeńskim, a także zapewnia godziwe zadowolenie ${ }^{100}$. Zapewne $\mathrm{z}$ tego względu i biorąc pod uwagę nauczanie św. Pawła, głosił, że mąż powinien odznaczać się omawianą cnotą, ponieważ jest głową żony $(1 \text { Kor } 11,3)^{101}$. Dlatego też w trosce o czystość małżeńską zalecał, by mężczyzna godziwie zawierał małżeństwo, chociaż, jak podkreślił, niektóre osoby wstydzą się z tego powodu. Innymi słowy, jak przekonuje biskup, człowiek chętnie znosi obecność świadków, gdy gniewa się na drugiego człowieka, aniżeli „spojrzenie choćby jednej osoby wtedy, gdy godziwie łączy się ze swą żoną"102. Podkreślał przy tym, że żaden mąż, nawet grzeszny, nie chce, by jego żoną była kobieta cudzołożna ${ }^{103}$. Uzupełnieniem tej myśli może być także stwierdzenie autora, który - opierając się na nauczaniu św. Pawła (Ef $5,23)$ - zauważa, że mąż, będąc głową żony, winien być tym, który jej przewodzi. $Z$ tego też tytułu powinien wystrzegać się dawania swym postępowaniem małżonce złego przykładu do naśladowania ${ }^{104}$.

habitent; quomodo vera ratione pudicum corpus asseritur, quando a vero Deo ipse animus fornicatur?"

${ }^{97}$ Tenże, Contra duas epistolas Pelagianorum, III, 5, 14; PL 44, 598: ,[...] de hac vita damnandus abscedat $[\ldots] "$.

${ }_{98}^{9}$ Tenże, De nuptiis et concupiscentia, I, 3, 3; PL 44, 415: „Ecce et hoc donum esse dixit a Deo".

${ }^{99}$ Tenże, De bono viduitatis, 17, 21; PL 40, 444. Por. J. Salij, Święty Augustyn o godności ptci, ,W Drodze” 8 (1975), s. 45.

${ }^{100}$ Św. Augustyn, Contra Julianum, IV, 2, 6; PL 44, 738: „Sed ego pro ipsa pudicitia coniugali dixi rogandum Deum [...]".

${ }^{101}$ Tenże, De coniugiis adulterinis, II, 2, 2; PL 40, 472. Por. J. Salij, Święty Augustyn..., dz. cyt., s. 47.

102 Św. Augustyn, De civitate Dei, XIV, 19; PL 41, 427: ,[...] magisque fert homo spectantium multitudinem, quando injuste irascitur homini, quam vel unius aspectum et quando iuste miscetur uxori”.

${ }^{103}$ Tenże, De nuptiis et concupiscentia, I, 17, 19; PL 44, 424.

${ }^{104}$ Tenże, De coniugiis adulterinis, II, 8, 7, PL 40, 475. Por. J. Salij, Święty Augustyn..., dz. cyt., s. 47. 
Stawiając za wzór św. Józefa ${ }^{105}$, św. Augustyn pochwalał tych, którzy w pożyciu małżeńskim dochowują cnoty czystości (pudicitia coniugalis) ${ }^{106}$, na przykład Scypiona Nazyka ${ }^{107}$ czy Waleriusza ${ }^{108}$, adresata De nuptiis et concupiscentia. Zdaniem autora, cnota ta jest dobrem człowieka, który ją osiagnął, ale też darem Bożym ${ }^{109}$ i powinnością ${ }^{110}$. Dochowujący bowiem czystości małżonkowie, jak podkreśla to św. Augustyn w polemice ze zwolennikami Pelagiusza, pragnęliby, gdyby mogli, płodzić dzieci, kierując się wolą, a nie lubieżną przyjemnością (pruriente voluptate) ${ }^{111}$. Mając to na uwadze, biskup Hippony w innym miejscu przypomniał, że ci, którzy nie dochowują czystości (castitas), nie mogą przystępować do Komunii św. ${ }^{112}$, nazywał ich też „zabójcami czystości” (homicida castitatis $)^{113}$. Zastanawiał się także, dlaczego mąż pragnie zniszczyć u cudzej żony to, co kocha u swojej. Odpowiadając na tak postawione pytanie, podkreślił, że winien on bardziej kochać czystość niż ciało swej żony. Kontynuując refleksję na ten temat, zauważył, że nikczemne jest myślenie (sordida cogitatio) tych, którzy przyznają, że kochają bardziej ciało niż czystość ${ }^{14}$.

Autor wyraził również przekonanie, że w gruncie rzeczy mąż kocha jednak bardziej czystość (pudicitiam) niż ciało, o czym świadczy jego stosunek do własnej córki. Pragnie bowiem, by jego córka zachowywała czystość. Jak dobitnie podkreśla autor, z tego względu mąż i ojciec winien kochać w sobie to, co kocha u swej córki, winien to także kochać u cudzej żony, ponieważ jego córka będzie kiedyś czyjąś żoną. To umiłowanie czystości i pokonywanie słabości w sobie samym ${ }^{115}$ stanie się zasługą na życie wieczne. Tę refleksję autor kończy stwierdzeniem, z którego wynika, że miłość do cudzej żony - w przeciwieństwie do czystości - nie jest wieczna ${ }^{116}$.

Nasz autor nie tylko miał świadomość, iż dochowanie czystości małżeńskiej sprawia trudność niejednemu człowiekowi ${ }^{117}$, ale był zdania, że namiętności na-

\footnotetext{
${ }^{105}$ Św. Augustyn, Sermones, 343, 6; PL 39, 1509.

106 Tenże, Epistolae, 151, 8; PL 33, 650; tenże, Sermones, 343, 6; PL 39, 1509.

107 Tenże, De civitate Dei, II, 5, PL 41, 51; Publius Cornelius Scipio Nasica Corculum był w roku 162 przed Chr. konsulem. Zmarł w 147 roku przed Chr.

${ }^{108}$ Św. Augustyn, De nuptiis et concupiscentia, I, 2, 2; PL 44, 414: ,[...] magna tibi est observantia pudicitiae coniugalis [...]". Por. A. Eckmann, Wprowadzenie..., dz. cyt., s. 16.

${ }_{109}$ Św. Augustyn, Epistolae, 200, 3; PL 33, 926.

${ }_{110}$ Tamże, 220, 12; PL 33, 997.

${ }^{111}$ Tenże, De nuptiis et concupiscentia, II, 31, 53; PL 44, 468: ,[...] casti sentiunt, qui procul dubio mallent, si possent, iubente voluntate quam pruriente voluptate filios seminare”.

${ }_{112}$ Tamże, 132, 4, 4; PL 38, 336: „Quicumque non servatis castitatem, nolite accedere ad illum panem $[\ldots]$ ".

113 Tenże, Sermones, 343, 7; PL 39, 1509.

114 Tamże, 343, 7; PL 39, 1510.

115 N. Blázquez, Feminismo..., dz. cyt., s. 41.

116 Św. Augustyn, Sermones, 343, 7; PL 39, 1509-1510.

117 Tenże, De bono coniugali, 15; PL 40, 385.
} 
leży hamować siła za pomocą łaski, której Bóg udziela ludziom ${ }^{118}$, oraz dobrego postępowania ${ }^{119}$. Stąd też zachęcał, by o tę cnotę się modlić ${ }^{120}$, praktykując równocześnie post i jałmużnę ${ }^{121}$, która polega nie tyle na dzieleniu się tym, co zbywa, ile na przykład na motywowanym miłością przebaczeniu komuś, kto obraził $^{122}$.

\subsection{Troska o cnotę wstrzemięźliwości}

Biskup Hippony z uznaniem wypowiadał się o niektórych katechumenach ${ }^{123}$ oraz o tych małżonkach, którzy postanowili żyć w braterskiej i siostrzanej więzi bez współżycia cielesnego, co - jego zdaniem - w małżeństwie chrześcijan jest „najwznioślejsze i najwyższe" 124 , służy bowiem dochowaniu wielkiego dobra, jakim jest boski dar wstrzemięźliwości ${ }^{125}$ (continentia) $^{126}$, którą autor stawiał wyżej niż czystość małżeńską ${ }^{127}$. Potwierdzenie tego znajdujemy także w stwierdzeniu, że „dobry chrześcijanin miłuje w jednej niewieście Boże stworzenie, dla którego pragnie przemiany i odnowienia, a nienawidzi połączenia i zbliżenia zniszczalnego i śmiertelnego". Kontynuując tę myśl, podkreślił, że oznacza to, iż małżonek ,miłuje w niej to, co jest człowiekiem, nienawidzi tego, co w niej jest tylko żoną"128. Stąd wydaje się zrozumiałe, że nie tylko pochwalał tych mężów, którzy potrafią przestrzegać tego, czego wymagają od swych żon, ale także odnosił się do tych, którzy ślubowali wstrzemięźliwość ${ }^{129}$. Ta refleksja obecna jest

118 Tenże, Contra Julianum, III, 21, 49; PL 44, 727.

119 Tamże.

${ }^{120}$ Tenże, De nuptiis et concupiscentia, I, 3, 3; PL 44,415; tenże, Contra Julianum, III, 21, 43; PL 44, 724.

${ }^{121}$ Tenże, Sermo, 9, 11, 17; PL 38, 88; tamże: 388; PL 39, 1700-1702; 389; PL 39, 1702-1705.

122 Tamże, 388; PL 39, 1700-1702; tamże: 389; PL 39, 1702-1705 (mowy wątpliwe). Por. J. Peters, Die Ehe nach der Lehre..., dz. cyt., s. 17.

${ }^{123}$ Św. Augustyn, In Joannis Evangelium Tractatus CXXIV, 4, 13; PL 35, 1411.

${ }^{124}$ Tenże, De sermone Domini in monte, I, 15, 42; PL 34, 1250: ,[...] habens uxorem tanquam non habens, quod est in coniugio Christianorum excellentissimum atque sublime [...]".

${ }^{125}$ Tenże, De bono viduitatis, 17, 21; PL 40, 444.

126 Tenże, Epistolae, 262, 9; PL 33, 1080-1081; tamże: 262, 10; PL 33, 1081: „[...] magnum continentiae bonum [...]"; 262, 11; PL 33, 1081-1082.

${ }^{127}$ Tenże, De nuptiis et concupiscentia, I, 3, 3; PL 44, 415: ,[...] etsi inferius quam illa continentia [...]".

${ }_{128}$ Tenże, De sermone Domioni in monte, I, 15, 41; PL 34, 1250: „Sic invenitur bonus christianus diligere in una femina creaturam Dei, quam reformari et renovari desiderat; odisse autem coniunctionem copulationemque corruptibilem atque mortalem: hoc est, diligere in ea quod homo est, odisse quod uxor est". Por. M. Müller, Die Lehre des hl. Augustinus von der Paradiesesehe und ihre Auswirkung in der Sexualethik des 12. und 13. Jahrhunderts bis Thomas von Aquin, Regensburg 1954, s. 32.

129 Św. Augustyn, Sermones, 132, 4, 4; PL 38, 336: „Congratulantur enim qui sciunt servare coniugibus, quod a coniugibus exigunt; qui sciunt servare omni modo continentiam, si hanc Deo voverunt $[\ldots] "$. 
również w innym miejscu, gdzie nasz autor przyznał, że niektórzy małżonkowie żyją we wstrzemięźliwości, nie szukając owocu ciała i nie wymagając od siebie spłacania długu pożądliwości cielesnej, lecz zachowując miłość małżeńską, nie łączą się cieleśnie, a sercem ${ }^{130}$.

Warto dodać, że biskup Hippony cnotę wstrzemięźliwości porównywał także z cnotą mądrości (sapientia). Uważał, że mądrość daje człowiekowi poznanie Boga, a dzięki powściagliwości człowiek nie upodabnia się do tego świata. Wyposażony w te cnoty człowiek staje się sprawiedliwy i doskonały ${ }^{131}$.

Zagadnienie wstrzemięźliwości w małżeństwie św. Augustyn rozpatrywał także w aspekcie ascetyczno-eschatologicznym. W jego przekonaniu w raju człowiek będzie żył jak aniołowie (Mt 22,30). Ten stan antycypuje już tu, na ziemi, życie we wstrzemięźliwości ${ }^{132}$, która poskramia i powstrzymuje żądze, pragnie nieśmiertelnego dobra, do którego dąży człowiek, odrzuca zło, z którym istota ludzka w swej śmiertelności walczy. Wstrzemięźliwość w przekonaniu naszego autora jest miłośniczką dobra, a wrogiem zła, dąży do piękna, a unika brzydoty. W życiu doczesnym tego rodzaju dobro można osiagnać wtedy, gdy nie przyzwala się na żądzę. Dobro to osiaga doskonałość, wtedy gdy ustanie żądza ${ }^{133}$. W wieczności bowiem ciało nie będzie pożądało przeciw duchowi ani duch przeciw ciału, zakończy się walka, w człowieku pogodzą się obydwie jego natury, nie będzie niczego cielesnego, a ciało będzie duchowe ${ }^{134}$. Tak więc według naszego autora bardziej szczęśliwe są te małżeństwa, które po bezdzietnym pożyciu czy też, wyrzekłszy się potomstwa ziemskiego, zachowują wstrzemięźliwość za obopólną zgodą. Taka decyzja nie sprzeciwia się przykazaniu zabraniającemu porzucania małżonki, gdyż nie porzuca małżonki mąż, który żyje z nią duchowo, a nie cieleśnie ${ }^{135}$.

Do dochowania cnoty wstrzemięźliwości zobowiązane są także osoby żyjące w separacji czy będące po rozwodzie z powodu cudzołóstwa jednego z małżonków ${ }^{136}$.

Podobnie, jak miało to miejsce w przypadku cnoty czystości małżeńskiej, biskup Hippony zachęcał do modlitwy o zachowanie tego, czego udzielił Bóg, i dopełnienie tego, czego jeszcze nie dał. Bóg bowiem, jak uczy nasz autor, wier-

\footnotetext{
${ }^{130}$ Tenże, Sermones, 51, 13, 21; PL 38, 345. Por. E. Albertario, Di alcuni riferimenti al matrimonio e al possesso di S. Agostino, „Studi di Diritto Romano” 1 (1933), s. 234.

${ }^{131}$ Św. Augustyn, De bono viduitatis, 17, 21; PL 40, 444.

${ }_{132}$ Tenże, De continentia, 3, 6; PL 40, 352-353; tamże: 11, 25; PL 40, 366-367. Por. J.M. Catalálan, El matrimonio en la obra pastoral de san Agustín, „Augustinus” 34 (1989), s. 86. ${ }^{133}$ Św. Augustyn, De continentia, 3, 6; PL 40, 353.

${ }^{134}$ Tamże, 11, 25; PL 40, 367.

135 Tenże, De sermone Domini in monte, I, 14, 39; PL 34, 1249; CC 35, 43; tenże, Sermo, 41, 21; PL 38, 345; tamże: 346 A, 6; PL S 2, 439; tenże, Epistolae, 199, 38; PL 33, 919; tenże, Enarrationes in Pslamos, 147, 4; CC 40, 2142. Por. J.M. Catalálan, El matrimonio..., dz. cyt., s. 86.

${ }^{136}$ Św. Augustyn, De coniugiis adulterinis, II, 13, 13, PL 40, 480.
} 
nych małżonków broni od cudzołóstwa i rozpusty, zaś świętym dziewicom i wdowom pomaga w zachowaniu całkowitej wstrzemięźliwości ${ }^{137}$.

\section{Człowiek wobec pożądliwości}

\subsection{Ocena pożądliwości}

Przestrzeganie cnoty czystości i wstrzemięźliwości sprawia trudności nawet tym „,czystym małżonkom”, którzy nakładają pożądliwości (concupiscentia) ${ }^{138}$ i żądzy (libido $)^{139}$ hamulce. Potwierdza to św. Augustyn, który wypowiada się na temat przeciwnego woli naporu pożądliwości ciała. Jego zdaniem, staje się on gwałtowny, kiedy pożądliwość doznaje podniety, chociażby nie doszło do grzechu, a nawet gdy wolą ujarzmia się pożądanie. W jego przekonaniu napięcie to pochodzi z prawa grzechu, którego działaniu podlegają z konieczności nawet powściągliwi ${ }^{140}$.

Niewątpliwie to przekonanie biskupa Hippony zrodziło się podczas jego polemiki z pelagianizmem, którego przedstawiciel, Julian z Eklanum, w swym dziele Ad Turbantium przekonywał, że powstanie namiętności przypisuje się ogniowi życiowemu, którego płomień powoduje pożądliwość ciała, która jest podstawą życia cielesnego ${ }^{141}$. Stąd też według tego przedstawiciela pelagianizmu odczuwanie tego rodzaju pożądania nie jest winą, niezależnie od tego, czy „rozpatrujemy jego rodzaj, gatunek czy sposób zaspokojenia". O winie człowieka decyduje jedynie jego nadużycie, ponieważ ludzki rodzaj i gatunek są dziełem Stwórcy. Innymi słowy, Julian był przekonany, że sposób zaspokojenia pożądliwości będzie dobry, jeśli człowiek podejmie uczciwą decyzję, zaś nadużycie jest spowodowane wadą jego woli ${ }^{142}$. Ponieważ założył, że pożądliwość jest dobrem, wyrażał też przekonanie, że cudzołożnicy źle się nim posługują, zaś czyści małżonkowie dobrze $^{143}$. Tenże Julian był także przekonany, że w porównaniu z małżonkami cudzołożnicy mniej grzeszą, ulegając pożądliwości, ,ponieważ małżonkom namiętność pomaga do grzechu, a cudzołożnikom go narzuca"144.

${ }^{137}$ Tenże, De bono viduitatis, 17, 21; PL 40, 444. Por. J. Salij, Święty Augustyn..., dz. cyt., s. 45.

${ }^{138} \mathrm{Na}$ temat pożądliwości cielesnej św. Augustyn wypowiada się między innymi w takich pismach, jak: De bono coniugali, 3, 3; PL 40, 375; De nuptiis et concupiscentia, I, 1, 1-2, 2; PL 44, 413-415; tamże: I, 12, 13; PL 44, 421; I, 17, 19; 44, 424-425; De gratia Christi et de peccato originali, II, 34, 39; PL 44, 404-405; De Genesi ad litteram, IX, 10, 16; PL 34, 398-399; De civitate Dei, XIV, 23-24; PL 41, 430-433. Por. W. Kornatowski, Społeczno-polityczna myśl św. Augustyna, Warszawa 1965, s. 166.

${ }^{139}$ Św. Augustyn, De nuptiis et concupiscentia, II, 9, 22; PL 44, 448.

${ }^{140}$ Tenże, Contra Julianum, II, 6, 15; PL 44, 684.

${ }^{141}$ Tamże, III, 13, 27; PL 44, 716; tenże, Ad Turbantium, 1.

${ }^{142}$ Tenże, Contra Julianum, III, 13, 27; PL 44, 716; tenże, Ad Turbantium, 1.

143 Tenże, Contra Julianum, III, 21, 49; PL 44, 727.

${ }^{144}$ Tamże, V, 16, 60; PL 44, 817; tenże, Ad Turbantium, 3, 61. 
Święty Augustyn starał się wyeksponować prawdę, że w raju przed grzechem pierworodnym, a więc zanim kara przyszła w ślad za winą, nie było cielesnej pożądliwości ani też nieuporządkowanych poruszeń, które są skutkiem grzechu pierworodnego ${ }^{145}$, tam też mogłyby rodzić się dzieci ${ }^{146}$. Podkreślał też, że ,jeśli sposób zaspokojenia pożądania zależy od uczciwej woli, to wola uczciwego małżonka pragnęłaby doznać poruszenia tego pożądania tylko w miarę potrzeby, a jednak nie zawsze on może, co chce", ponieważ, konkluduje św. Augustyn, „decyzja woli nie ma żadnej władzy nad samym pożądaniem, które w swych objawach nie jest umiarkowane, dlatego uczciwy duch nakłada pożądaniu hamulce”147. Stąd też, jak przekonuje autor, „powściagliwość lepiej czyni, nie zadowalając tego popędu", który jest zły ${ }^{148}$. Nie można także z jednej strony, tu widać aluzję do wypowiedzi Juliana, chwalić pożądliwości, a z drugiej być jej wrogiem $^{149}$. Biskup Hippony zaznaczył również, że nie zgadza się $\mathrm{z}$ twierdzeniami Juliana z Eklanum, według którego namiętność jest godna czci, kiedy służy małżonkom do krzewienia życia ${ }^{150}$. Odrzucił też przypisywany mu przez Juliana pogląd, że każde zaspokojenie namiętności jest grzeszne, ponieważ nie jest grzechem dobre posługiwanie się złem ${ }^{151}$. W przekonaniu św. Augustyna grzeszy tylko ten, kto uniewinnia namiętność, a nie ten, kto dobrze posługuje się tym złem $^{152}$, które, jak czytamy w innym miejscu, „nie jest dobrem małżeństwa, lecz nieprzyzwoitością grzeszących, koniecznością rodzących, płomieniem swawoli, wstydem małżeństwa"153 i chorobą (morbus) ${ }^{154}$.

Wypowiadając te słowa, autor zdawał sobie sprawę z tego, że zdarzają się mężczyźni niezadowoleni z własnych żon, którzy kierując się pożądliwością ${ }^{155}$, myślą o cudzołóstwie, ponieważ nie chcą ujarzmić pożądania ciała ${ }^{156}$.

\footnotetext{
${ }^{145}$ Tenże, Contra Julianum, III, 13, 27; PL 44, 716. Por. W. Kornatowski, Społeczno-polityczna myśl..., dz. cyt., s. 166.

146 Św. Augustyn, Contra Julianum, III, 24, 54; PL 44, 730.

${ }^{147}$ Tamże, III, 13, 27; PL 44, 716.

148 Tamże, III, 21, 49; PL 44, 727.

149 Tamże, III, 21, 50; PL 44, 728.

${ }^{150}$ Tamże, V, 16, 60; PL 44, 817; tenże, De nuptiis et concupiscentia, I, 13; PL 44, 421; tenże, Ad Turbantium, 3.

${ }^{151}$ Tenże, Contra Julianum, V, 16, 60; PL 44, 817; tenże, Ad Turbantium, 3.

${ }^{152}$ Tenże, Contra Julianum, V, 16, 60; PL 44, 817. Por. W. Kornatowski, Spoleczno-polityczna myśl..., dz. cyt., s. 166.

${ }^{153}$ Św. Augustyn, De nuptiis et concupiscentia, I, 12; PL 44, 422: „Non est igitur haec libido nuptiarum bonum, sed obscoenitas peccantium, necessitas generantium, lasciviarum ardor, nuptiarum pudor"; tamże: II, 9, 22, PL 44, 449.

${ }_{154}$ Tamże, I, 8, 9; PL 44, 418.

155 Tenże, Sermones, 8, 5, 6; PL 38, 70.

156 Tamże, 8, 5, 6; PL 38, 69-70.
} 


\subsection{Zachęta do przezwyciężania pożądliwości}

By zapobiec wspomnianym w poprzednim paragrafie zjawiskom, biskup Hippony nie ograniczał się tylko do oceny pożądliwości, ale usilnie zachęcał do jej opanowania. Jego zdaniem, aby dochować czystości oraz wstrzemięźliwości, należy podjąć zwycięską walkę z pożądliwością (libido). Dopiero w tak podjętej walce ujawnia się posiadana przez małżonka cnota ${ }^{157}$. Zapewne mając to na uwadze, autor zauważył, że pożądanie jest wspólne zarówno człowiekowi, jak i zwierzętom. Zwierzęta łączą się w pary i wydają na świat potomstwo, ale nie na wszystko sobie pozwalają ${ }^{158}$. Zgodnie z natura, którą stworzył Bóg, tylko w określonym czasie „czują pociąg do parzenia się”, później pożądanie ustaje. Nie działa u nich także rozum ${ }^{159}$.

Człowiek natomiast różni się od nich myśleniem i rozumowaniem (ratiocinari, intelligere), więc - zdaniem autora - jego rozum winien panować nad niższymi instynktami, ujarzmiać je, okiełznać, by nie działały w sposób niegodziwy.

W przeciwieństwie do zwierząt człowiek zawsze może odczuwać pożądanie, ponieważ zdolny jest do pohamowania $\mathrm{go}^{160}$. Bóg bowiem dał mu jako wodzów władzę rozumu (dominatio rationis) oraz przykazanie czystości (praecepta continentiae). Dzięki temu może on powstrzymywać się od tego, od czego zwierzęta nie mogą, i żywić nadzieję osiagnięcia życia wiecznego, na co zwierzęta nie mogą liczyć161. Innymi słowy, naszemu autorowi chodzi przede wszystkim o to, by obecna w człowieku nieuporządkowana pożądliwość została poddana władzy ducha ${ }^{162}$.

Gdy natomiast człowiek, nie panując nad pożądliwością, wzgardzi tymi wartościami i zlekceważy to, że został stworzony na obraz Boga, to stanie się bydlęciem, zatraci w sobie człowieczeństwo. Nie będzie jednak miał natury bydlęcej, ale - pozostając w postaci ludzkiej - upodobni się do bydlęcia ${ }^{163}$. W takiej sytuacji winien przynajmniej lękać się śmierci ${ }^{164}$.

Komentując przemyślenia biskupa Hippony, Niceto Blázquez zauważa, że człowiek jako całość, a więc mężczyzna i kobieta, mąż i żona, ma panować nad pożądliwością cielesną ${ }^{165}$. Jego wnioski wynikają z pism starożytnego autora,

157 Tamże, Sermones, 332, 4; PL 38, 1463. Por. L. Anné, La conclusion du mariage..., dz. cyt., s. 522.

${ }^{158}$ Św. Augustyn, Sermones, 8, 5, 6; PL 38, 70.

159 Tamże, 8, 5, 6; PL 38, 69-70.

${ }^{160}$ Tamże.

${ }^{161}$ Tamże, Sermones, 8, 5, 6; PL 38, 69-70; tamże: 8, 5, 6; PL 38, 70.

${ }^{162}$ W. Kornatowski, Społeczno-polityczna myśl..., dz. cyt., s. 166.

${ }^{163}$ Św. Augustyn, Sermones, 8, 5, 6; PL 38, 70.

164 Tamże.

165 Tamże, 51, 13, 22; PL 38, 345; N. Blázquez, Feminismo agustiniano, „Augustinus” 27(1982), s. 3-53. 
który odwołując się do nauczania św. Pawła (1 Kor 6, 15.19-20), zwraca się do małżonków dochowujących sobie wierności oraz osób niezamężnych, by nie dopuszczali się nierządu, ponieważ człowiek jest członkiem Chrystusa i świątynią Ducha Świętego ${ }^{166}$. Nasz autor, powołując się po raz kolejny na nauczanie Apostoła Narodów (1 Tes 4,3-5), przypomina, że Bóg chce, by małżonkowie uświęcali się i powstrzymywali się od nierządu, utrzymywali swe naczynia (małżonki) w świętości i czci, a nie kazili ich pożądliwością, jak poganie nieznający $\mathrm{Boga}^{167}$. To oznacza, że wierzący małżonek nie tylko nie powinien pożądać cudzych żon, ale także nie wolno mu własnej żony podporządkowywać namiętności ${ }^{168}$. Posiłkując się nauczaniem św. Pawła, który polecał małżonkom miłowanie własnych żon (Kol 3,19), oraz św. Jana (1 J 2,15-17), dobitnie zaznacza, że mąż nie może w żonie ani w sobie samym miłować cielesnej pożądliwości, gdyż pożądliwość ciała, oczu i pycha tego świata nie pochodzi od Ojca, ale od świata i wraz z pożądliwością przeminie ${ }^{169}$.

W przekonaniu św. Augustyna św. Paweł nie zabraniał małżonkom pożycia, które jest dozwolone (licitum) i godziwe (honestum), ale uczył, że jest to „takie obcowanie, które nie wynika z wolnej woli, ale konieczności, bez której w rodzeniu dzieci nie można osiągnąć owocu tejże woli. Jest to więc obcowanie, które nie miałoby nic ze skażonej żądzy, gdyby wskutek uprzedniego grzechu nie została zniszczona w nim [obcowaniu] wolna wola"170.

\subsection{Sposoby panowania nad pożądliwością}

Święty Augustyn nie tylko ocenił pożądliwość i skierował słowa zachęty do jej przezwyciężania, ale podał także szereg sposobów jej pokonywania. Podkreślił więc, że prawdziwy mężczyzna nie będzie ulegał pożądliwości, którą symbolizuje kobieta, ale nad nią panował ${ }^{171}$. Stąd też dla św. Augustyna ujarzmienie kobiety oznacza zdyscyplinowanie własnych namiętności ${ }^{172}$. Myśl tę uzupełnia stwierdzenie naszego autora, w którym stara się uwypuklić prawdę, że „duch ludzki jest dla duszy jakby mężem, który rządzi skłonnościami zwierzęcymi (ani-

166 Tenże, De bono viduitatis, 6, 8; PL 40, 435.

${ }^{167}$ Tenże, De nuptiis et concupiscentia, I, 8, 9; PL 44, 418.

168 Tamże, I, 8, 9; PL 44, 418.

${ }^{169}$ Tamże, I, 18, 20; PL 44, 425: „Absit ergo ut fidelis homo [...] concupiscentiam carnis diligat in uxore, quam nec in se ipso debet diligere [...]".

170 Tamże, I, 8, 9; PL 44, 419.

171 Tenże, De vera religione, 41, 78, PL 34, 157. Por. N. Blázquez, Feminismo..., dz. cyt., s. 8. Dla wyjaśnienia należy dodać, że według św. Augustyna mężczyzna nie jest uosobieniem rozumu, a kobieta zmysłów, gdyż nie ma różnicy pomiędzy mężczyzną i kobietą (św. Augustyn, De Genesi ad litteram imperfectus liber, 16, 54-62; PL 34, 241-244; tenże, De opere monachorum, 32, 40; PL 40, 580).

${ }^{172}$ Tenże, De vera religione, 41, 78, PL 34, 157. Por. N. Blázquez, Feminismo..., dz. cyt., s. 9. 
malem affectionem) jak małżonką" 173 i dlatego „o tyle umysł chwalebniej unosi się ku temu co wyższe, o ile pilniej od tego co niższe powściagga się pożądliwość". Proces ten, w przekonaniu św. Augustyna, będzie zakończony dopiero w chwili zmartwychwstania, które odzieje człowieka niezniszczalnością i nieśmiertelnością, a więc zwycięstwem nad śmiercią ${ }^{174}$. Mówiąc inaczej, to podporządkowanie kobiecej sfery seksualnej mężczyźnie jest symbolem odnowienia wewnętrznego mężczyzny i kobiety, którzy biorąc pod uwagę perspektywę przyszłego zmartwychwstania, panują nad niskimi popędami ${ }^{175}$. Stąd też, jego zdaniem, istotnym czynnikiem w walce z pożądliwością jest trwanie w bojaźni Bożej. Komentując bowiem list św. Pawła do Galatów $(5,24)$, zauważył, że ukrzyżowanie ludzkiego ciała wraz z namiętnościami i pożądliwością dokonuje się w czystej i szczerej bojaźni Bożej, która trwa na wieki (Ps 18,10) ${ }^{176}$. W kontekście tej wypowiedzi zrozumiałe wydaje się spostrzeżenie biskupa Hippony, że skutecznym remedium na zło pożądliwości cielesnej, z którą się człowiek rodzi, jest „lek odrodzenia", jakim jest chrzest, a następnie dobre życie ${ }^{177}$.

Konsekwencją tego jest dążenie do osobistej świętości, do czego zachęca nasz autor, mając na uwadze, że powaby tego świata są dobrami przemijający$\mathrm{mi}^{178}$. W walce $\mathrm{z}$ pożądliwością ogromne znaczenie ma także modlitwa (Mt 6,13; Jk 1,14$)^{179}$, podczas której małżonkowie świadomi tego, że w ich ciałach nie przebywa dobro (Rz 7,18), oderwani od zła błagają o dobre posługiwanie się złem goszczącym w ich ciałach, proszą, by nie pozostało w nich żadne zło, którym mieliby się posługiwać180.

W pokonywaniu pożądliwości pomagają nie tylko środki nadprzyrodzone, ale także szereg środków o charakterze przyrodzonym. Wspominał o tym św. Augustyn, który do sposobów walki z pożądliwością zaliczał podporządkowywanie jej rozumowi i cnocie, brał bowiem pod uwagę to, że mężczyzna i kobieta są obrazem Boga, w którym realizuje się rzeczywistość człowieka niezależnie od płci ${ }^{181}$. Wobec tego małżonkowie mogą się uchronić, jak zapewniał św. Augustyn, przed różnymi zboczeniami pochodzącymi od namiętności ${ }^{182}$.

Dzięki zachowywaniu cnoty powściągliwości człowiek hamuje pożądliwość, walcząc z buntowniczymi jej poruszeniami, co prowadzi w miarę postępu do jej pokonywania. W ten sposób według św. Augustyna można opanować zło, a nie

\footnotetext{
${ }_{173}$ Św. Augustyn, De diversis quaestionibus LXXXIII, 64, 7; PL 40, 58.

174 Tenże, De opere monachorum, 32, 40; PL 40, 580.

${ }_{175}$ N. Blázquez, Feminismo..., dz. cyt., s. 13.

176 Św. Augustyn, Expositio Epistolae ad Galatas, 53; PL 35, 2142.

177 Tenże, Contra Julianum, III, 21, 49; PL 44, 727.

${ }^{178}$ Tenże, De bono viduitatis, 20, 25; PL 40, 447.

179 Tamże.

${ }^{180}$ Tenże, Contra Julianum, IV, 2, 6; PL 44, 738-739.

${ }^{181}$ N. Blázquez, Feminismo..., dz. cyt., s. 7.

${ }^{182}$ Św. Augustyn, Contra Julianum, V, 16, 60; PL 44, 817.
} 
- jak wynika to z poglądów Juliana - dobro. Dlatego też według biskupa Hippony Julian w istocie pochwalał pożądliwość i nie nakazywał hamowania jej przez powściagliwość ${ }^{183}$. Mając zapewne to na uwadze, w kontekście nauki o małżeństwie nasz autor zauważa, że nie tylko nie jest ono [małżeństwo] złem, jak twierdzili to na przykład manichejczycy, ale ma ono umiejętność dobrego posługiwania się złem pożądliwości, gdy przekazuje życie potomstwu ${ }^{184}$. Do tak sformułowanej myśli biskup Hippony dodał uwagę, że Julian, walcząc z pożądliwością, pośrednio wskazywał na to, że jest ona $\mathrm{w}$ istocie $\mathrm{złem}^{185}$. Tak więc według św. Augustyna małżeństwo jest lekarstwem na chorobę pożądliwości. Jego celem nie jest wywołanie pożądliwości na wypadek jej nieistnienia, lecz powstrzymanie jej pędu do niegodziwych poruszeń ${ }^{186}$.

W pożyciu małżeńskim człowiek posługuje się złem pożądliwości, ale nie jest przez nią zwyciężany, ponieważ pożądliwość rozpaloną nieuporządkowanymi i nieskromnymi poruszeniami hamuje (fraenat) i powściagga (cohibet) ${ }^{187}$. Święty Augustyn zachęcał więc żonatych mężczyzn, by w cierpliwości ${ }^{188}$ i w duchu podległym sprawiedliwości zwalczali w sobie namiętność, nie pozwolili „ześlizgnąć się $\mathrm{z}$ tego co moralne w stosunkach małżeńskich poza to, co w nich wymaga zrodzenia potomstwa oraz poza znane przepisy porządku natury, przyjętych obyczajów i praw”189. Podkreślał też, że „dobra wola duszy kieruje towarzyszącymi przyjemnościami ciała i nie idzie za ich rozkazami, ani też grzech nie zniewala ludzkiej woli" ${ }^{190}$. Innymi słowy, w przekonaniu naszego autora, w obecnym czasie każdy żyjący według Chrystusa walczy z pożądliwością ciała, powściąga jego naturę, by ją uleczyć, a z drugiej strony karmi i pielęgnuje dobrą jego naturę, gdyż nikt swego ciała nie darzy nienawiścią (Ef 5,29) ${ }^{191}$.

To, że pożądliwość można przezwyciężyć, potwierdza przykład nawrócenia pewnego małżonka, który prawdopodobnie albo pożądał cudzej, piękniejszej żony lub innej bogatszej od własnej. Nie uległ jednak grzechowi, gdyż posłuchał słowa Bożego. Nasz autor, dokonując pewnego rodzaju analizy psychologicznej rodzącej się i narastającej pokusy, zauważył, że nogi owego męża „chętnie już kierowały się ku upadkowi, ale trzymały je kajdany słowa Bożego, bojaźń Boża

\footnotetext{
${ }_{183}$ Tamże, III, 21, 49; PL 44, 727.

${ }^{184}$ Tamże, III, 24, 54; PL 44, 730.

185 Tamże, III, 21, 50; PL 44, 728.

${ }^{186}$ Tamże, IV, 2, 6; PL 44, 738-739.

${ }^{187}$ Tenże, De nuptiis et concupiscentia, I, 8, 9; PL 44, 419.

${ }^{188}$ Tenże, Sermones, 8, 5, 6; PL 38, 70.

${ }_{189}$ Tenże, De bono coniugali, 26, 34; PL 40, 396.

${ }^{190}$ Tenże, De nuptiis et concupiscentia, I, 12; PL 44, 421: „,...] bona voluntas animi, sequentem ducit, non ducentem sequitur corporis voluptatem; nec humanum arbitrium trahitur subiugante peccato, cum iuste redigitur [...]"; Contra Julianum, V, 16, 59; PL 44, 816. Por. W. Eborowicz, Wstęp, w: Św. Augustyn, Przeciw Julianowi, Warszawa 1977, s. 24.

${ }^{191}$ Św. Augustyn, De continentia, 11, 25; PL 40, 367.
} 
oraz strach przed potępieniem”. Jak przekonywał biskup Hippony, człowiek ów podjął autorefleksję, podczas której doszedł do przekonania, że Bóg słyszy jęki jego żony oraz że zostanie poczytany za winnego przed Jego obliczem. W związku z tym uznał, że jego „żądza schlebia, jednak kara go przeraża”"192. Tę refleksję, naszym zdaniem, autor podjął ponownie w innym miejscu, gdzie wspomniał o pewnym człowieku, który postępując zgodnie ze swą wiara, znosił swą niewstrzemięźliwość przez skromność małżeńską, wypełniał cielesny obowiązek małżeński nie tylko ze względu na prokreację, ale także z powodu pożądliwości współżyjąc ze swoją żona, na co małżonkom zezwolił św. Paweł (1 Kor 7,6), oraz przyjmował z cierpliwością nie tylko doświadczane niesprawiedliwości. Taki człowiek, w przekonaniu św. Augustyna, osiagnie po śmierci nagrodę wieczną ${ }^{193}$.

Zdaniem biskupa Hippony, małżonkowie chrześcijańscy powinni tak postępować, ponieważ winni tworzyć nowe małżeństwo (novas nuptias), którego ozdobą są cnoty, a nie ozdoby zewnętrzne (non monilibus), powinni oni być czyści, święci i dobrzy, aby doczekać się nowych zaślubin w niebieskim Jeruzalem ${ }^{194}$.

\section{Wnioski}

Analiza nauczania św. Augustyna na temat kształtowania samoświadomości moralnej małżonka prowadzi do następujących wniosków.

1. Nasz autor, charakteryzując małżonka, nie przywiązywał szczególnej wagi do jego urody osobistej, ale kładł nacisk na jego przymioty osobiste, do których zaliczał między innymi wykształcenie i kulturę osobista, otwartość i uczuciowość, skromność, dobroć, troskę o zachowanie właściwiej hierarchii wartości, w której na pierwszym miejscu znajdują się miłość Boga, siebie samego i bliźniego. Biskup Hippony pochwalał również troskę męża o biednych, przede wszystkim zaś o dom i swych najbliższych, a zwłaszcza o zachowanie pokoju wśród jego mieszkańców. Uważał bowiem, że od pokoju panującego w poszczególnych rodzinach zależy pokój w państwie.

Charakteryzując osobowość małżonka, zwracał również uwagę na jego pokorę oraz umiłowanie ojczyzny.

2. Z nauczania biskupa Hippony wynika, że każdy mężczyzna, również małżonek, winien także pracować nad sobą, a zwłaszcza troszczyć się o do-

${ }^{192}$ Tenże, Enarrationes in Psalmos, 149, 15; PL 37, 1959.

193 Tenże, Contra duas epistolas Pelagianorum, III, 5, 14; PL 44, 598.

194 Tenże, Sermones, 332, 4; PL 38, 1463. Por. L. Anné, La conclusion du mariage..., dz. cyt., s. 522 . 
bro wyrażające się w dobrych obyczajach. Święty Augustyn nie tylko zachęcał do unikania zła i czynienia pokuty za popełnione grzechy, ale wskazywał kierunki i pola pracy nad soba. Zalecał szczególnie troskę o wypracowywanie w sobie cnót, dzięki którym mężczyzna będzie przykładem dla swej żony, duchowym wsparciem i przewodnikiem $(d u x)$, którego będzie starała się naśladować.

Święty Augustyn wielką wage przywiązywał do wypracowania w sobie cnoty czystości (castitas) nie tylko wobec żony, ale każdej kobiety. Za wzór do naśladowania stawiał postawę św. Józefa wobec Maryi. Według św. Augustyna wielką pomocą jest w tym przypadku łaska Boża, dobre postępowanie oraz modlitwa połączona z postem i jałmużna.

Cnotą wysoko cenioną przez naszego autora jest także wstrzemięźliwość (continentia), którą stawiał wyżej aniżeli czystość małżeńską, ponieważ jej pielęgnowanie antycypuje już tu, na ziemi, życie człowieka w raju.

Obowiązkiem osób żyjących w separacji lub będących po rozwodzie jest praktykowanie tej cnoty. O jej posiadanie należy także się modlić.

3. Pisma św. Augustyna zawierają także ocenę pożądliwości (concupiscentia) i żądzy (libido) mężczyzny i małżonka. Nauka naszego autora na ten temat zrodziła się w kontekście jego polemiki z pelagianizmem. Biskup Hippony był przekonany, że w raju przed grzechem pierworodnym nie było cielesnej pożądliwości ani też nieuporządkowanych poruszeń, które są skutkiem grzechu pierworodnego. Stąd tak pożądliwość, jak i namiętność oceniał jako zło. Jednak w jego przekonaniu nie popełnia grzechu ten, kto dobrze posługuje się tym złem.

Nasz autor nie tylko dokonał oceny pożądliwości, ale także zachęcał do jej przezwyciężania za pomocą argumentów rozumowych, cnót czystości i wstrzemięźliwości, trwania w bojaźni Bożej, troski o osobistą świętość. Wielką rolę przypisywał także modlitwie.

Dla św. Augustyna uzasadnieniem takiego postępowania, zwłaszcza małżonków chrześcijańskich, jest to, że winni oni tworzyć nowe małżeństwo (novas nuptias), którego ozdobą są cnoty czystości, świętość i dobroć. Postępując w ten sposób i kierując się tymi wartościami, małżonkowie podążają do nowych zaślubin w niebieskim Jeruzalem. 


\section{Shaping of the Husband's Moral Awareness in the Teaching of St. Augustine of Hippo}

\section{Summary}

The article is divided into two paragraphs. The first paragraph presents St. Augustine's opinion on the husband as a person. His remarks on the appearance as well as the personal values of a man and husband are discussed.

The second paragraph deals with the issue of personality formation, including such points as the care to form moral goodness, especially the virtues of chastity and continence. This paragraph also considers St. Augustine's view on concupiscence. The bishop of Hippo not only assesses concupiscence but also gives encouragement to overcome it and at the same time suggests methods that enable its control.

\section{Keywords}

St. Augustine, man, husband, moral goodness, chastity, continence, concupiscence, self-awareness

\section{Słowa kluczowe}

św. Augustyn, mężczyzna, mąż, dobroć moralna, czystość, wstrzemięźliwość, pożądliwość, samoświadomość 